\title{
Manejo sanitário destinado aos bezerros em propriedades produtoras de leite no município de Batalha/AL
}

Rayane Caroline Medeiros do Nascimento, Lucas Adonys Teixeira da Silva, Viviane Melo Coelho Barros, Walter Franklin Bernardino Leão Filho, George Tenório Pereira de Oliveira, Gabriel Regis Guerrieri Esperidião, Anderson Silva de Oliveira, Wagnner José Nascimento Porto, Andressa Rodrigues Sabino, Gildeni Maria Nascimento de Aguiar

Curso de Medicna Veterinária, Universidade Federal de Alagoas (UFAL), Arapiraca, AL, Brasil

*Autor correspondente

e-mail: gildeni.aguiar@vicosa.ufal.br

\section{Resumo}

Uma das fontes de renda e perpetuação dos rebanhos leiteiros são as bezerras, futuras matrizes e produtoras de leite, e é nesta esfera que concentra-se grande parte dos problemas da bovinocultura leiteira. Diante do exposto, o presente trabalho objetiva determinar o perfil sanitário e aspectos do manejo destinados aos bezerros no Município de Batalha, em Alagoas. Entre agosto e dezembro de 2016 foram visitadas 21 propriedades, a cujos responsáveis foram aplicados questionários para obtenção de informações a respeito do manejo sanitário e nutricional dos animais. Os rebanhos das propriedades totalizaram 1.924 animais, dos quais 340 (17,6\%) eram bezerros com menos de um ano de idade. Apenas 28,57\% (6/21) das propriedades possuíam piquete maternidade e 80,95\% (17/21) respeitavam o período seco das vacas. Em 71,42\% (15/21), os neonatos mamavam colostro na própria vaca, e para 28,57\% (6/21) o colostro era administrado em mamadeira, sendo que 66,66\% (4/6) ofertavam dois litros por vez e 44,44\% (2/6) até seis litros; 42,85\% (9/21) preocupavam-se em administrar colostro até seis horas após o nascimento. Nenhuma das fazendas fazia banco de colostro. Após a colostragem, o aleitamento era feito ao pé da vaca em $71,42 \%$ (15/21) das propriedades e em 28,57\% (6/21) era feito aleitamento artificial com pool leite. Nestas últimas, 66,66\% (4/6) recebiam até cinco litros de leite, enquanto que 44,44\% (2/6) recebiam apenas dois. Em 42,85\% (9/21), os bezerros eram mantidos em alojamentos coletivos a pasto, com cocho para água e ração, e sem separação por idade. 19,04\% (4/21) tinham bezerreiros argentinos; 38,09\% (8/21) tinham o hábito de separar os animais sadios dos doentes; e 33,33\% (7/21) das propriedades fazem quarentena. A idade média ao desmame foi de um mês em 33,33\% (7/21) das fazendas, 42,85\% (9/21) em até sete meses e 23,8\% (5/21) acima dos sete meses. 76,19\% (16/21) dos produtores faziam cura do umbigo, sendo que destes 43,75\% (7/16) utilizavam iodo e 56,25\% (9/16) usavam repelente em spray. As doenças mais 
frequentes foram diarreia e broncopneumonia em 71,42\% (15/21) e 47,61\% (10/21), respectivamente. 71,42\% (15/21) não sabiam, ou mesmo não tratavam a broncopneumonia; 19,04\% (4/21) utilizavam tratamento caseiro; e 9,52\% (2/21) acionavam o médico veterinário. 57,14\% (12/21) dos tratadores não sabiam informar como tratava-se a diarreia, 23,81\% (5/21) acreditavam que só diminuindo a ingestão de leite havia cura do bezerro e 19,05\% (4/21) utilizavam tratamento caseiro. A endoparasitose foi relatada por 38,09\% (8/21) produtores. 61,90\% (13/21) dos produtores fazem uso de vermífugos, dos quais 38,46\% (5/13) começam a utilizar vermífugos nos bezerros com menos de 60 dias e 61,53\% (8/13) só começam vermifugar a partir dos 60 dias. A caracterização dos rebanhos e a determinação dos pontos críticos em relação ao manejo dos bezerros são medidas essenciais para o direcionamento de futuras recomendações aos produtores rurais e monitoramento dos rebanhos. 